\title{
Five Years Before the Masthead: Our Journey with the Journal of General Internal Medicine
}

\author{
William M. Tierney, $M D^{1,2,5}$, Martha S. Gerrity, MD, PhD 3,4 , and Cindy Byrne ${ }^{2}$ \\ ${ }^{1}$ Indiana University School of Medicine, Indianapolis, IN, USA; ${ }^{2}$ Regenstrief Institute, Inc, Indianapolis, IN, USA; ${ }^{3}$ Oregon Health \& Science

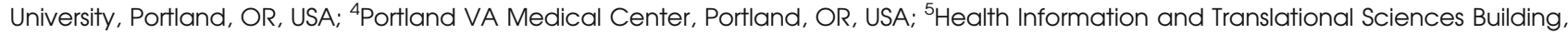 \\ Indianapolis, IN, USA.
}

J Gen Intern Med 24(12):1349-55

DOI: $10.1007 / \mathrm{s} 11606-009-1188-1$

(c) Society of General Internal Medicine 2009

\section{INTRODUCTION}

As in Richard Henry Dana's classic American seafaring novel, Two Years Before the Mast ${ }^{1}$, our time at the helm of the Journal of General Internal Medicine (JGIM) has been filled with adventure. We have charted our course with specific goals and objectives while navigating the shoals of increasing time commitments for editors and reviewers while facing the rising storm of e-publishing. In this five-year retrospective, we reflect upon this journey, assess the degree to which we met our goals, and discuss lessons learned from which our successors may build and sail a stouter ship.

In 2004, we were pleased to be chosen as the fifth set of editors of JGIM. In our proposal to the Council of the Society of General Internal Medicine (SGIM), we listed five specific goals and objectives we would attempt to achieve during our tenure (Table 1). Attacking these goals has been a challenge, a significant learning experience, and quite rewarding for all three of us. Because this is the last issue of the Journal to be published during our tenure as editors, we wanted to take this opportunity to document the degree to which we have met those initial goals and speculate upon JGIMs future.

\section{GOAL 1: INCREASE THE NUMBER OF PEER-REVIEWED ARTICLES PUBLISHED}

During the five years prior to the current editorship (2000-2004), the mean number of manuscripts received per year was 694 (increasing from 480 to 937). The mean number of "regular articles" (i.e., excluding editorials, reflections, book and media reviews, and letters to the editor) was 594, increasing from 381 in 2000 to 788 in 2004 (Fig. 1). By comparison, during the five years of our editorship (July 1, 2004 through June 30, 2009), we received 4,879 manuscripts (not counting manuscripts submitted to supplements or special issues), a mean of 976 per year, a $41 \%$ increase over the prior five years. A total of 4,273 "regular articles" were submitted during the past five years, a mean of 855 per year, a $44 \%$ increase over the prior five years.

Published online November 20, 2009
From 2000 through 2004, a mean of 126 articles (range 107 to 134) were published per year in regular issues of JGIM (i.e., not including supplements). This increased by $121 \%$ to 271 per year (range 201 to 279) during the first four years of our editorship. (Data for 2009 are incomplete at this time.) We reached this goal of increasing published articles through a number of planned objectives aimed at making the most of JGIMs page budget, including 1) reducing the maximum number of words per article from 3,500 to 3,000 for most article types; 2) making greater use of Brief Reports; 3) publishing appendices online only; and 4) improving the formatting of JGIM articles to reduce the amount of white space. We were also able to increase the number of published articles when, in 2007, JGIM changed its publisher to Springer who raised JGIM's page budget dramatically.

Maximizing space and increasing JGIMs page budget allowed us to increase the acceptance rate for regular articles (excluding editorials, reflections, book reviews, and letters to the editor) from $20 \%$ during the final year of our predecessors to $25-26 \%$ from 2005 through 2007. Increasing the acceptance rate was not a stated goal. Rather, we told our Deputy Editors to accept for publication all articles they felt were worthy of publication in JGIM.

\section{GOAL 2: INCREASE THE NUMBER OF PUBLISHED ARTICLES ON MEDICAL EDUCATION}

In 2003, SGIM's Education Committee was dissatisfied with the small number of articles on medical education being published in JGIM. It therefore made a formal request to the SGIM Council to publish a new journal dedicated to medical education. Although this proved not to be financially viable, we committed to increasing the number of medical education articles in JGIM. As shown in Figure 2, JGIM published a mean of 13 medical education articles per year during the five years prior to our editorship. This included the 37 articles published in 2004 in the first Medical Education Special Issue, without which the mean number of articles per year on medical education would have been only 5.6. The number articles on medical education topics more than tripled to a mean of 41 per year from 2005 through 2008. However, JGIM published a greater number of articles from 2005 through 2008, so the proportion of medical education articles only increased from $10 \%$ to $15 \%$ of all articles published.

We accomplished this increase in published articles focusing on medical education in several ways. First, we had a coeditor-in-chief (MSG) and 12 Deputy Editors whose main focus was medical education. Second, we advertised JGIM's interest in publishing medical education articles through an editorial ${ }^{2}$ and repeated discussions with the SGIM council, JGIM's 
Table 1. Original Goals and Objectives in 2004 Proposed by the JGIM Co-Editors

Goal \# 1: Increase the number of peer-reviewed articles published.

Objective 1.1: Reduce the number of words per article.

Objective 1.2: Make greater use of Brief Reports.

Objective 1.3: Make greater use of the Internet.

Objective 1.4: Improve formatting of JGIM articles

Goal \#2: Increase the number of published articles on medical education

Objective 2.1: Have a co-editor and Deputy Editors who are nationally recognized medical educators.

Objective 2.2: Advertise JGIM's emphasis on medical education.

Objective 3.3: Increase the number of supplements.

Goal \#3: Substantially decrease review time.

Objective 3.1: Invoke a model of Deputy Editors and distributed editorial decision-making.

Objective 3.2: Use the Regenstrief Institute's manuscript management system.

Objective 3.3: Convert to $100 \%$ electronic format for submitting manuscripts and managing reviews.

Objective 3.4: Take full advantage of electronic communication in processing manuscripts and editorial decision-making.

Goal \#4: Increase the number of sponsored supplements and special issues

Goal \#5: Evolve to an online journal.

Objective 5.1: Submit content from 1996 to 12 months after publication to PubMed Central for open access.

Objective 5.2: Increase the amount of appendix material published only in the Web-based version of JGIM.

Objective 5.3: E-mail JGIM's electronic tables of contents to subscribers.

editorial board, and with readers and authors during SGIM's annual meeting. And third, we published calls for papers for JGIM's biennial Medical Education Special Issue. The 2006 and 2008 Medical Education Special Issues received 90 and 136 manuscripts, of which we published 31 (34\%) and 42 articles (31\%), respectively.

\section{GOAL 3: SUBSTANTIALLY DECREASE REVIEW TIME}

Disappointingly, we did not achieve this goal. Prior to our editorship, the editors-in-chief and most of the Associate Editors were members of a single division of general internal medicine. Editorial decisions were made among the editor-in-

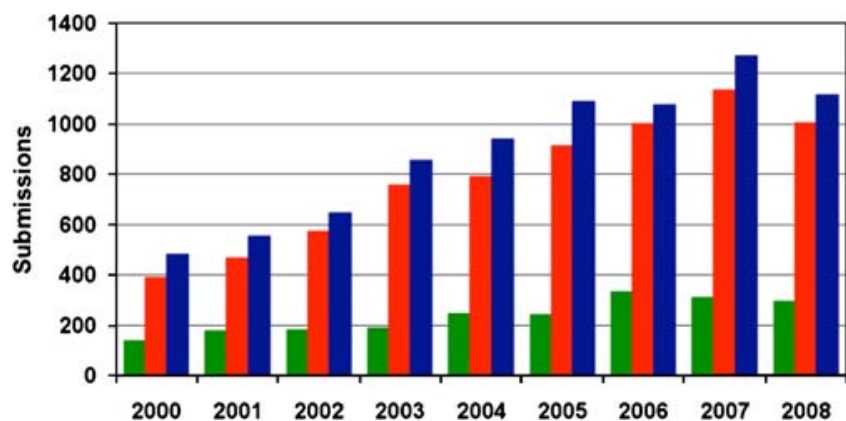

Figure 1. Manuscripts received and articles published by year from 2000 through 2008. The current editors began accepting manuscripts July 1, 2004. The blue bars represent all manuscripts and the red bars represent "regular" manuscripts, which excludes editorials, reflections, book and media reviews, and letters to the editor. The green bars represent articles published.

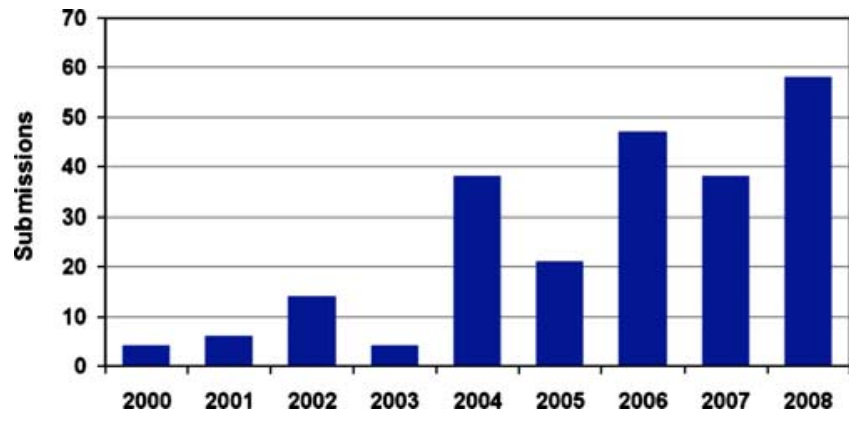

Figure 2. Published articles whose primary focus was medical education.

chief and a mostly local group of Associate Editors in monthly editorial meetings. Because JGIMs submissions were growing, and the focus among the manuscripts submitted to JGIM was broad, we felt a one-division model was too constraining: we did not want to restrict our ability to find the best Associate Editors with sufficient breadth of expertise. So, we invoked the model that one of us (WMT) had employed as co-editor-inchief of Medical Care: we empanelled a corps of Deputy Editors with broad content expertise as well as geographic and demographic diversity. And because they had the requisite content expertise, we empowered these Deputy Editors to make the editorial decisions to accept or reject manuscripts, using us and the other Deputy Editors as consultants when necessary.

This model worked quite well for making editorial decisions. During our five-year tenure, we employed 57 Deputy Editors with wide-ranging expertise (Table 2). At any one time, JGIM had approximately 30 Deputy Editors. In addition to editorial decisionmaking, the Deputy Editors also recommended manuscripts for editorials (and had the option of writing them), press releases, and immediate open-access, an option that is available for 24 articles per year through an agreement between JGIM and its publisher.

However, the model had its downside: JGIM's Managing Editor and Associate Managing Editor had to communicate with a large, widely dispersed continent of Deputy Editors, and this took time. Also, having a large number of volunteer (i.e., unpaid) Deputy Editors practically guaranteed that there would be some whose "day jobs" would require their attention and thus distract their attention from managing JGIM manuscripts, which would lead to delays.

During the same period, time demands on JGIM's reviewers increased in response to financial pressures on academic medical centers. Hence, to obtain commitments from three peer reviewers to review a manuscript within three weeks, the number of persons the managing editors had to contact rose from 10-12 per manuscript in 2005 to more than 25 in 2008. Consequently, review time for articles undergoing full peerreview increased from 62 days in 2004 to 79 days in 2008 (Fig. 3). In response, we and the Deputy Editors and editorial board members collectively decided to restrict external review to those articles with the greatest likelihood of being accepted for publication after close scrutiny by the Deputy Editor. As a result, the number of manuscripts rejected without external peer review increased from $25 \%$ in 2005 to $51 \%$ in 2008 . This counterbalanced the increased time for peer-reviewed articles, and thus the review time for all manuscripts remained stable (Fig. 3). 
Table 2. JGIM Deputy Editors, 2004 through 2009, by Initial Year

\begin{tabular}{|c|c|c|c|}
\hline Deputy Editor & Academic Institution & $\begin{array}{l}\text { Began } \\
\text { Term }\end{array}$ & $\begin{array}{l}\text { Endec } \\
\text { Term }\end{array}$ \\
\hline $\begin{array}{l}\text { Jasjit Ahluwalia, } \\
\text { MD, MPH }\end{array}$ & $\begin{array}{l}\text { Universities of Kansas } \\
\text { and Minnesota }\end{array}$ & 2004 & 2006 \\
\hline $\begin{array}{l}\text { Andrew Auerbach, } \\
\text { MD, MPH }\end{array}$ & $\begin{array}{l}\text { University of California, } \\
\text { San Francisco }\end{array}$ & 2004 & 2007 \\
\hline $\begin{array}{l}\text { Arlene Bierman, MD, } \\
\text { MS }\end{array}$ & $\begin{array}{l}\text { Agency for Healthcare } \\
\text { Research and Quality }\end{array}$ & 2004 & 2006 \\
\hline Judith Bowen, MD & $\begin{array}{l}\text { Oregon Health and } \\
\text { Science University }\end{array}$ & 2004 & 2008 \\
\hline $\begin{array}{l}\text { Helen Burstin, } \\
\text { MD, MPH }\end{array}$ & $\begin{array}{l}\text { Agency for Healthcare } \\
\text { Research and Quality }\end{array}$ & 2004 & 2005 \\
\hline $\begin{array}{l}\text { Caroline Carney } \\
\text { Doebbeling, } \\
\text { MD, MSc }\end{array}$ & Indiana University & 2004 & 2005 \\
\hline Robert Centor, MD & $\begin{array}{l}\text { University of Alabama } \\
\text { at Birmingham }\end{array}$ & 2004 & 2005 \\
\hline $\begin{array}{l}\text { Marshall, Chin, } \\
\text { MD, MPH }\end{array}$ & University of Chicago & 2004 & 2009 \\
\hline Marion Danis, MD & $\begin{array}{l}\text { National Institutes } \\
\text { of Health }\end{array}$ & 2004 & 2008 \\
\hline $\begin{array}{l}\text { Leonard Egede, } \\
\text { MD, MS }\end{array}$ & $\begin{array}{l}\text { University of South } \\
\text { Carolina }\end{array}$ & 2004 & 2009 \\
\hline $\begin{array}{l}\text { Richard Frankel, } \\
\text { PhD }\end{array}$ & Indiana University & 2004 & 2009 \\
\hline $\begin{array}{l}\text { Gustavo } \\
\text { Heudebert, MD }\end{array}$ & $\begin{array}{l}\text { University of Alabama } \\
\text { at Birmingham }\end{array}$ & 2004 & 2006 \\
\hline $\begin{array}{l}\text { Richard Hoffman, } \\
\text { MD, MPH }\end{array}$ & University of New Mexico & 2004 & 2009 \\
\hline Ronnie Horner, $\mathrm{PhD}$ & University of Cincinnati & 2004 & 2009 \\
\hline $\begin{array}{l}\text { Adina Kalet, MD, } \\
\text { MPH }\end{array}$ & New York University & 2004 & 2008 \\
\hline $\begin{array}{l}\text { Michael Landry, MD, } \\
\text { MSc }\end{array}$ & Tulane University & 2004 & 2009 \\
\hline $\begin{array}{l}\text { Victor Montori, MD, } \\
\text { MSc }\end{array}$ & $\begin{array}{l}\text { Mayo Clinic College } \\
\text { of Medicine }\end{array}$ & 2004 & 2005 \\
\hline Anna Reisman, MD & Yale University & 2004 & 2007 \\
\hline $\begin{array}{l}\text { Somnath Saha, MD, } \\
\text { MPH }\end{array}$ & $\begin{array}{l}\text { Oregon Health and } \\
\text { Science University }\end{array}$ & 2004 & 2008 \\
\hline Wally Smith, MD & $\begin{array}{l}\text { Virginia Commonwealth } \\
\text { University }\end{array}$ & 2004 & 2005 \\
\hline $\begin{array}{l}\text { David Stern, } \\
\text { MD, PhD }\end{array}$ & University of Michigan & 2004 & 2006 \\
\hline Wanzhu Tu, PhD & Indiana University & 2004 & 2008 \\
\hline $\begin{array}{l}\text { Judith Walsh, MD, } \\
\text { MPH }\end{array}$ & $\begin{array}{l}\text { University of California, } \\
\text { San Francisco }\end{array}$ & 2004 & 2009 \\
\hline $\begin{array}{l}\text { Morris Weinberger, } \\
\text { PhD }\end{array}$ & $\begin{array}{l}\text { University of North } \\
\text { Carolina }\end{array}$ & 2004 & 2005 \\
\hline $\begin{array}{l}\text { Brent Williams, } \\
\text { MD, MPH }\end{array}$ & University of Michigan & 2004 & 2008 \\
\hline $\begin{array}{l}\text { Julia Arnsten, MD, } \\
\text { MPH }\end{array}$ & $\begin{array}{l}\text { Albert Einstein College } \\
\text { of Medicine }\end{array}$ & 2005 & 2007 \\
\hline $\begin{array}{l}\text { Hayden Bosworth, } \\
\text { PhD }\end{array}$ & Duke University & 2005 & 2009 \\
\hline $\begin{array}{l}\text { Carlos Estrada, } \\
\text { MD, MS }\end{array}$ & $\begin{array}{l}\text { University of Alabama } \\
\text { at Birmingham }\end{array}$ & 2005 & 2007 \\
\hline $\begin{array}{l}\text { Jennifer Haas, MD, } \\
\text { MSPH }\end{array}$ & Harvard University & 2005 & 2008 \\
\hline $\begin{array}{l}\text { Jeffrey Jackson, } \\
\text { MD, MPH }\end{array}$ & $\begin{array}{l}\text { Uniformed Services } \\
\text { University of Health } \\
\text { Sciences }\end{array}$ & 2005 & 2009 \\
\hline $\begin{array}{l}\text { Claudia Steiner, } \\
\text { MD, MPH }\end{array}$ & $\begin{array}{l}\text { Agency for Healthcare } \\
\text { Research and Quality }\end{array}$ & 2005 & 2007 \\
\hline $\begin{array}{l}\text { Jeffrey Whittle, } \\
\text { MD, MPH }\end{array}$ & $\begin{array}{l}\text { Medical College } \\
\text { of Wisconsin }\end{array}$ & 2005 & 2009 \\
\hline $\begin{array}{l}\text { Lori Bastian MD, } \\
\text { MPH }\end{array}$ & Duke University & 2006 & 2009 \\
\hline $\begin{array}{l}\text { Malaz Boustani, } \\
\text { MD, MPH }\end{array}$ & Indiana University & 2006 & 2008 \\
\hline $\begin{array}{l}\text { Tracie Collins, MD, } \\
\text { MPH }\end{array}$ & University of Minnesota & 2006 & 2008 \\
\hline $\begin{array}{l}\text { David Cook, MD, } \\
\text { MHPE }\end{array}$ & $\begin{array}{l}\text { Mayo Clinic College } \\
\text { of Medicine }\end{array}$ & 2006 & 2009 \\
\hline
\end{tabular}

Table 2. (continued)

\begin{tabular}{|c|c|c|c|}
\hline Deputy Editor & Academic Institution & $\begin{array}{l}\text { Began } \\
\text { Term }\end{array}$ & $\begin{array}{l}\text { Ended } \\
\text { Term }\end{array}$ \\
\hline Jennifer Kogan, MD & University of Pennsylvania & 2006 & 2009 \\
\hline $\begin{array}{l}\text { Thomas Sequist, MD, } \\
\text { MPH }\end{array}$ & Harvard University & 2006 & 2009 \\
\hline $\begin{array}{l}\text { Anderson } \\
\text { Spickard, MD, } \\
\text { MPH }\end{array}$ & Vanderbilt University & 2006 & 2009 \\
\hline Diane Wayne, MD & Northwestern University & 2006 & 2009 \\
\hline $\begin{array}{l}\text { Paul Aronowitz, } \\
\text { MD }\end{array}$ & $\begin{array}{l}\text { California Pacific Medical } \\
\text { Center }\end{array}$ & 2007 & 2009 \\
\hline Andrew Dunn, MD & $\begin{array}{l}\text { Mount Sinai School } \\
\text { of Medicine }\end{array}$ & 2007 & 2009 \\
\hline $\begin{array}{l}\text { Alex Federman, } \\
\text { MD, MPH }\end{array}$ & $\begin{array}{l}\text { Mount Sinai School } \\
\text { of Medicine }\end{array}$ & 2007 & 2009 \\
\hline $\begin{array}{l}\text { Elizabeth Jacobs, } \\
\text { MD, MPP }\end{array}$ & Rush University & 2007 & 2009 \\
\hline Neeta Jain, MD & $\begin{array}{l}\text { California Pacific Medical } \\
\text { Center }\end{array}$ & 2007 & 2009 \\
\hline $\begin{array}{l}\text { Michael Rothberg, } \\
\text { MD, MPH }\end{array}$ & Tufts University & 2007 & 2009 \\
\hline $\begin{array}{l}\text { Jodi Segal, MD, } \\
\text { MPH }\end{array}$ & Johns Hopkins University & 2007 & 2009 \\
\hline $\begin{array}{l}\text { Christina Wee, MD, } \\
\text { MPH }\end{array}$ & Harvard University & 2007 & 2009 \\
\hline $\begin{array}{l}\text { Ronald } \\
\text { Ackermann, MD, } \\
\text { MPH }\end{array}$ & Indiana University & 2008 & 2009 \\
\hline $\begin{array}{l}\text { Caleb Alexander, } \\
\text { MD, MS }\end{array}$ & University of Chicago & 2008 & 2009 \\
\hline $\begin{array}{l}\text { Edward Ellerbeck, } \\
\text { MD, MPH }\end{array}$ & University of Kansas & 2008 & 2009 \\
\hline $\begin{array}{l}\text { Lauris Kaldjian, } \\
\text { MD, PhD }\end{array}$ & University of Iowa & 2008 & 2009 \\
\hline Mukta Panda, MD & $\begin{array}{l}\text { University of Tennessee } \\
\text { at Chattanooga }\end{array}$ & 2008 & 2009 \\
\hline Melissa Partin, PhD & University of Minnesota & 2008 & 2009 \\
\hline $\begin{array}{l}\text { Hoangmai Pham, } \\
\text { MD, MPH }\end{array}$ & $\begin{array}{l}\text { Center for Studying Health } \\
\text { System Change }\end{array}$ & 2008 & 2009 \\
\hline $\begin{array}{l}\text { W. Scott } \\
\text { Richardson, MD }\end{array}$ & Wright State University & 2008 & 2009 \\
\hline $\begin{array}{l}\text { Colin West, MD, } \\
\text { PhD }\end{array}$ & $\begin{array}{l}\text { Mayo Clinic College } \\
\text { of Medicine }\end{array}$ & 2008 & 2009 \\
\hline
\end{tabular}

\section{GOAL 4: INCREASE THE NUMBER OF SPONSORED SUPPLEMENTS AND SPECIAL ISSUES}

By publishing supplements and special issues relevant to JGIM's mission, we could increase the Journal's pages without cost to SGIM while generating modest income to the Society through royalties. Supplements and special issues could also bring focus to issues important to SGIM and its members. Therefore, in our original proposal, we committed to increasing the number of sponsored supplements and special issues.

During the five years prior to our editorship, JGIM published one supplement and one special issue, both in 2004. As shown in Table 3, during our tenure from 2005 through 2009, JGIM published four special issues and nine supplements. Although we received in queries from medical education companies about publishing supplements sponsored by the pharmaceutical industry, we only considered proposals with topics that were central to the mission of SGIM and where the funder did not have a financial conflict of interest. Importantly, each supplement and special issue was managed, at least in part, by one or more of JGIMs Deputy Editors. All manuscripts were 


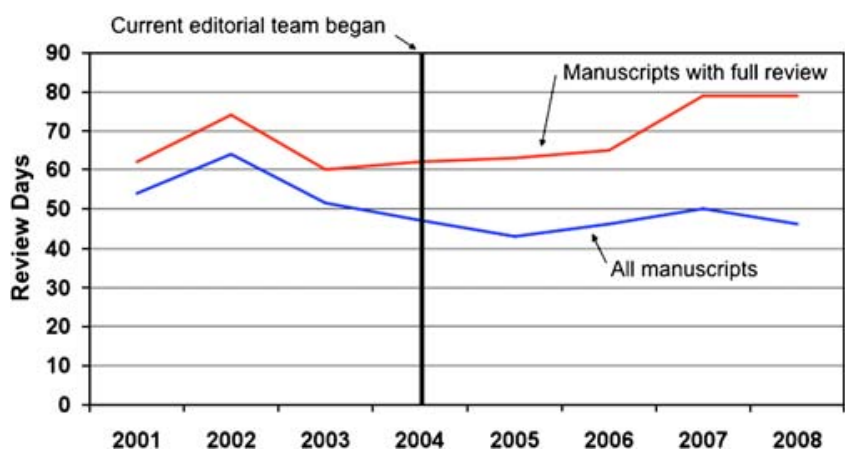

Figure 3. Manuscript management time. The red line represents manuscripts sent out for external peer-review. The blue line represents all manuscripts, including those that were sent out for external review and those that were not send out for external review.

peer-reviewed, and some were rejected from each supplement and special issue. In several supplements, the quality of the articles published was quite high. For example, of the top 20 articles published in 2006 (assessed by the number of full-text downloads), 13 (65\%) were published in supplements or special issues ${ }^{5}$. The Department of Veterans Affairs, Agency for Healthcare Quality and Research, and Robert Wood Johnson Foundation have each funded multiple JGIM supplements over the past five years (Table 3).

\section{GOAL 5: EVOLVE TO AN ONLINE JOURNAL}

In an attempt to facilitate manuscript management, JGIM used the manuscript management system that the Regenstrief Institute, Inc. had previously created for Medical Care. Written in MS-Access ${ }^{\circledR}$, this system provides the editors with the ability to customize the manuscript management system's content and function to match local policies and procedures for manuscript and journal management. In addition, having the full database available for analysis greatly facilitated the editors' management of the Journal and assessing of the quality of peer-review. For example, JGIMs database provided information for a paper describing JGIM reviewers' internal consistency and reliability that was presented at an international conference on journal editing in $2009^{3}$. The next JGIM editors have decided to keep the current system, which was given free to SGIM by the Regenstrief Institute.

To decrease the time and costs of manuscript reviews, we exclusively used e-mail to communicate with authors, Deputy Editors, and reviewers. All manuscripts were submitted through a Website created by JGIM's programmer ${ }^{4}$, which was also used to post JGIMs Instructions for Authors and announcements (e.g., calls for papers for supplements and special issues). This resulted in substantial savings, as JGIMs budget for mailing was practically nil.

We also took several steps to increase our use of electronic media and make JGIM more accessible to our readers. When we took over JGIM's editorship, JGIM content had not been sent to PubMed Central for open access. The process of reformatting prior JGIM content to PubMed Central's specifications took more than two years. However, since 2006, all JGIM content from 1996 has been made freely available through PubMed Central 12 months after publication. Additionally, when JGIM switched to Springer as its publisher in 2007, Springer digitized all back issues of JGIM. Now, all JGIM issues from 1986 to present are available electronically through SpringerLink.

The greater availability of JGIM content through the online edition of JGIM has resulted in a dramatic increase in global readership via full-text downloads. As shown in Figure 4, the number of full-text articles downloaded increased tenfold from 103,363 in 2003 to 1,046,499 in 2008 , with a peak of $1,140,296$ in 2007 . Since 2007, the bulk of downloads have been via PubMed Central. The number of downloads dwarfs the number of articles being accessed by individual and institutional subscribers of the paper edition of JGIM. Truly, JGIM has become an international electronic journal. We further leveraged JGIM's electronic content by having SGIM e-mail an electronic table of contents to all SGIM members, in addition to individuals who have signed up to receive them (which increased from 190 to 445 in 2008). Thus, SGIM members and others whose institutions have consortium agreements with Springer can peruse the electronic table of contents and access selected articles electronically from their personal computers and mobile devices.

\section{IMPACT FACTORS AND OTHER RELATIVE MEASURES OF SUCCESS}

Thompson's Institute for Scientific Information (ISI) produces a number of statistics in an attempt to rank journals by their impact on their readers. The most commonly cited is the Journal Impact Factor, which is calculated by summing the number of citations in a year to articles published in the two prior years ${ }^{6}$. Based on its impact factor, JGIM's ranking among general and internal medicine journals dropped from 15th in 2003 to 25 th in 2008. The absolute value of the impact factor decreased only slightly, from 2.81 in 2003 to 2.72 in 2008 , while the total number of citations more than doubled, from 3,874 in 2003 to 8,020 in 2008 . The Impact Factor dropped because the number of published articles rose even faster than the number of citations, and also because we published categories of articles that traditionally have few citations: medical education articles, qualitative research, case reports, and clinical vignettes. Ironically, while JGIMs actual impact has increased substantially (as measured by the number of times that others are citing and downloading its articles), its Impact Factor ranking has dropped significantly.

Others have suggested that the Impact Factor is an inadequate or even inappropriate measure of journal quality ${ }^{7}$, and alternative measures have been suggested ${ }^{8}$. For example, in 2008 JGIM was ranked 15th among general and internal medicine journals in ISI's Five-Year Impact Factor, 10th in Eigenfactor (Five-Year Impact Factor excluding self-citations), 15th in the Article Influence Score (Five-Year Impact Factor adjusted by the number of articles published), but only 42 nd in Immediacy Index (the mean number of times that an article published in a year was cited in that year), and 57th in Cited Half-Life (number of years one has to go back to account for the total number of citations).

Nevertheless, many academic and commercial leaders use the Impact Factor to judge the value of a journal, and by 
Table 3. JGIM Supplements and Special Issues, 2006 through 2009

\begin{tabular}{|c|c|c|c|c|c|}
\hline Supplement Name & Description & Sponsor & Editors & $\begin{array}{l}\text { No. of } \\
\text { Articles }\end{array}$ & $\begin{array}{l}\text { Publication } \\
\text { Date }\end{array}$ \\
\hline $\begin{array}{l}\text { Relationship } \\
\text { Centered } \\
\text { Care Supplement }\end{array}$ & $\begin{array}{l}\text { Papers from the biennial } \\
\text { Regenstrief conference }\end{array}$ & $\begin{array}{l}\text { Regenstrief } \\
\text { Institute, Inc. }\end{array}$ & Rich Frankel, Martha Gerrity & 9 & $\begin{array}{l}\text { January } \\
2006\end{array}$ \\
\hline $\begin{array}{l}\text { Translation } \\
\text { Research } \\
\text { Methods } \\
\text { Supplement }\end{array}$ & $\begin{array}{l}\text { Papers from a VA } \\
\text { State-of-the-Art } \\
\text { Conference }\end{array}$ & $\begin{array}{l}\text { Department } \\
\text { of Veterans } \\
\text { Affairs }\end{array}$ & $\begin{array}{l}\text { Catarina Kiefe, Victor Montori, } \\
\text { Anne Sales }\end{array}$ & 8 & $\begin{array}{l}\text { February } \\
2006\end{array}$ \\
\hline $\begin{array}{l}\text { Women's Health } \\
\text { Supplement }\end{array}$ & $\begin{array}{l}\text { Call for papers on issues } \\
\text { relevant to health care } \\
\text { of women veterans }\end{array}$ & $\begin{array}{l}\text { Department } \\
\text { of Veterans Affairs }\end{array}$ & $\begin{array}{l}\text { Ronnie Horner, Donna } \\
\text { Washington, Rebecca Yano }\end{array}$ & 14 & $\begin{array}{r}\text { March } \\
2006\end{array}$ \\
\hline $\begin{array}{l}\text { Medical Education } \\
\text { Special Issue }\end{array}$ & $\begin{array}{l}\text { Biennial call for papers } \\
\text { on medical education }\end{array}$ & $\begin{array}{l}\text { Society of General } \\
\text { Internal Medicine }\end{array}$ & $\begin{array}{l}\text { Stewart Babbott, Carol Bates, } \\
\text { Judy Bowen, David Stern, } \\
\text { Brent Williams }\end{array}$ & 31 & May 2006 \\
\hline $\begin{array}{l}\text { Health Literacy } \\
\text { Special Issue }\end{array}$ & $\begin{array}{l}\text { Call for papers } \\
\text { on health literacy }\end{array}$ & Pfizer & $\begin{array}{l}\text { Sunil Kripalani, } \\
\text { Michael Paasche-Orlow, } \\
\text { Ruth Parker, Somnath Saha }\end{array}$ & 14 & $\begin{array}{c}\text { August } \\
2006\end{array}$ \\
\hline $\begin{array}{l}\text { Spirituality/ Religion } \\
\text { and Quality of Life in } \\
\text { Patients with HIV } \\
\text { Supplement }\end{array}$ & $\begin{array}{l}\text { Papers from a multicenter } \\
\text { longitudinal study } \\
\text { of patients with HIV }\end{array}$ & $\begin{array}{l}\text { National Institutes } \\
\text { of Health }\end{array}$ & Hayden Bosworth, Joel Tsevat & 10 & $\begin{array}{l}\text { December } \\
2006\end{array}$ \\
\hline $\begin{array}{l}\text { Limited English } \\
\text { Proficiency } \\
\text { Supplement }\end{array}$ & $\begin{array}{l}\text { Call for papers on communication } \\
\text { and limited English proficiency } \\
\text { in health care research and policy }\end{array}$ & $\begin{array}{l}\text { Robert Wood } \\
\text { Johnson } \\
\text { Foundation }\end{array}$ & $\begin{array}{l}\text { Eliseo Perez-Stable, } \\
\text { Alicia Fernandez, } \\
\text { Somnath Saha }\end{array}$ & 21 & $\begin{array}{l}\text { October } \\
2007\end{array}$ \\
\hline $\begin{array}{l}\text { Managing complexity } \\
\text { in chronic care } \\
\text { Supplement }\end{array}$ & $\begin{array}{l}\text { Papers from a VA } \\
\text { State-of-the-Art Conference }\end{array}$ & $\begin{array}{l}\text { Department } \\
\text { of Veterans Affairs }\end{array}$ & $\begin{array}{l}\text { Hayden Bosworth, } \\
\text { Geraldine McGlynn, } \\
\text { Jeffrey Whittle, Kevin Weiss }\end{array}$ & 12 & $\begin{array}{l}\text { December } \\
2007\end{array}$ \\
\hline $\begin{array}{l}\text { New and Emerging } \\
\text { Technologies } \\
\text { Supplement }\end{array}$ & $\begin{array}{l}\text { Papers from a special } \\
\text { SGIM symposium conducted } \\
\text { and a call for papers }\end{array}$ & $\begin{array}{l}\text { Blue Shield } \\
\text { of California } \\
\text { Foundation }\end{array}$ & $\begin{array}{l}\text { Mitchell Feldman, } \\
\text { Richard Hoffman, } \\
\text { Claudia Steiner, Jeffrey Tice }\end{array}$ & 17 & $\begin{array}{l}\text { January } \\
2008\end{array}$ \\
\hline $\begin{array}{l}\text { Health Information } \\
\text { Technology } \\
\text { Special Issue }\end{array}$ & $\begin{array}{l}\text { Call for papers on uses } \\
\text { of information technology } \\
\text { to advance the quality and } \\
\text { efficiency of health care } \\
\text { and medical education. }\end{array}$ & $\begin{array}{l}\text { Agency for Healthcare } \\
\text { Research and Quality }\end{array}$ & $\begin{array}{l}\text { David Cook, Jennifer Haas, } \\
\text { Ronnie Horner, Tomas } \\
\text { Sequist William Tierney }\end{array}$ & 28 & April 2008 \\
\hline $\begin{array}{l}\text { Medical Education } \\
\text { Special Issue }\end{array}$ & $\begin{array}{l}\text { Biennial call for papers } \\
\text { on medical education }\end{array}$ & $\begin{array}{l}\text { Society of General } \\
\text { Internal Medicine }\end{array}$ & $\begin{array}{l}\text { Judy Bowen, David Cook, } \\
\text { Martha Gerrity, Adina } \\
\text { Kalet, Elizabeth Jacobs, } \\
\text { Jennifer Kogan, Anderson } \\
\text { Spickard, Diane Wayne }\end{array}$ & 43 & July 2008 \\
\hline $\begin{array}{l}\text { Cancer Survivorship } \\
\text { Supplement }\end{array}$ & $\begin{array}{l}\text { Conference papers } \\
\text { and call for papers }\end{array}$ & $\begin{array}{l}\text { Lance Armstrong } \\
\text { Foundation }\end{array}$ & Lori Bastian, Jeffrey Jackson & 20 & $\begin{array}{l}\text { November } \\
2009\end{array}$ \\
\hline $\begin{array}{l}\text { Quality of Care } \\
\text { for Latinos } \\
\text { Supplement }\end{array}$ & $\begin{array}{l}\text { Papers from an initiative } \\
\text { on quality of care } \\
\text { and health care disparities } \\
\text { among Latinos }\end{array}$ & $\begin{array}{l}\text { Robert Wood Johnson } \\
\text { Foundation }\end{array}$ & $\begin{array}{l}\text { Hayden Bosworth, } \\
\text { Ronnie Horner }\end{array}$ & 8 & $\begin{array}{l}\text { December } \\
2009\end{array}$ \\
\hline VA QUERI Supplement & $\begin{array}{l}\text { Papers from a VA } \\
\text { State-of-the-Art Conference }\end{array}$ & $\begin{array}{l}\text { Department } \\
\text { of Veterans } \\
\text { Affairs }\end{array}$ & $\begin{array}{l}\text { Jeffrey Whittle, } \\
\text { Jodi Segal }\end{array}$ & 12 & $\begin{array}{l}\text { January } \\
2010\end{array}$ \\
\hline
\end{tabular}

that measure JGIMs falling Impact Factor is a concern. To counter the downward trajectory of JGIMs Impact Factor, the editors as a group decided to lower JGIMs manuscript acceptance rate, which subsequently dropped from $26 \%$ in 2007 to $22 \%$ in 2008 and $21 \%$ for the first half of 2009 . We also decided to restrict case reports and clinical vignettes to SGIM members, which has cut their volume by more than $80 \%$. Due to the way that the Impact Factor is calculated, it will take several years for the full impact of these changes to fully manifest themselves.

\section{INNOVATIONS AND CHANGES}

We and our Deputy Editors made several changes to enhance journal content and readability. We added several new categories of articles, including Case Reports and Clinical Vignettes, Hospital Medicine ${ }^{9}$, Updates (presented at SGIM's Annual Meeting), Teaching Tips, and most recently Point-Counterpoint. We recruited several Deputy Editors with expertise in qualitative research-JGIM is one of the few clinical journals that welcomes qualitative research. In the past year, we also published three important SGIM Policy and Position Papers on academic hospital medicine ${ }^{10}$, pay-for-performance ${ }^{11}$, and health care transitions $^{12}$ (the latter in collaboration with the American College of Physicians, the Society of Hospital Medicine, the American Geriatrics Society, the American College of Emergency Physicians, and the Society of Academic Emergency Medicine). The position papers on hospital medicine and health care transitions were simultaneously published in the Journal of Hospital Medicine. We eliminated Book and Media Reviews because both formal and informal feedback from readers sug- 


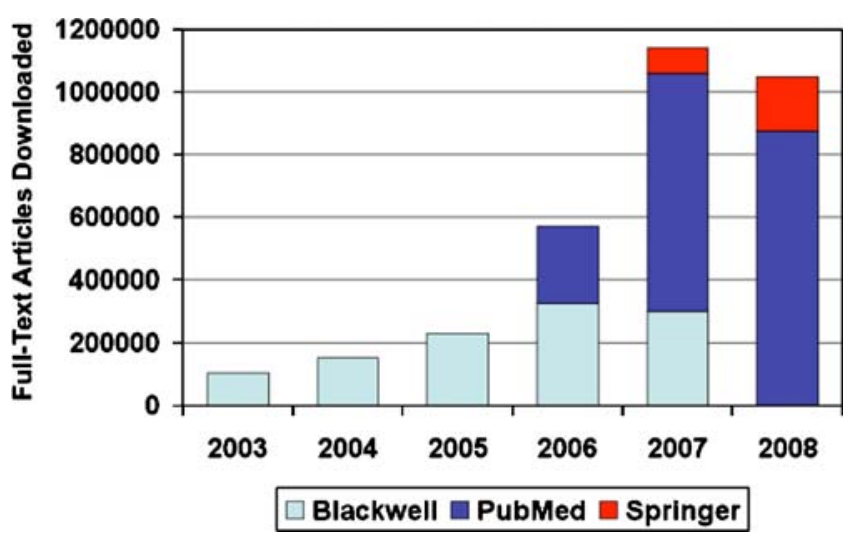

Figure 4. Number of full-text articles downloaded by year. The light blue bars represent articles downloaded from the online edition of JGIM at Blackwell Science. The dark blue bars represent full-text articles downloaded from PubMed. The red bars represent full-text articles downloaded from JGIM's online edition at Springer, which became JGIM's publisher in 2007.

gested that these were seldom read. We encouraged submissions of systematic reviews and meta-analyse ${ }^{13}$, which both clinicians and educators find useful, and articles on hospital medicine (recognizing the increasing number of hospitalists among the ranks of general internists) ${ }^{9}$. We discouraged non-systematic reviews and, in partnership with the World Association of Medical Editors, came out strongly against articles ghost-written by medical education companies that are funded by the pharmaceutical industry ${ }^{14-16}$.

In an attempt to encourage our colleagues to provide peer reviews of manuscripts, each December we publicly recognized outstanding reviewers based on the number, timeliness, and quality of their reviews ${ }^{17}$. We also submitted letters of recognition to these reviewers' academic department heads and, when requested, wrote letters for promotion of reviewers who had served JGIM well. And a few of the most outstanding reviewers were invited to join JGIMs Deputy Editor corps.

When we first engaged Springer to be JGIMs publisher in 2007, Springer made it clear that they wanted to be SGIM's publisher for more than JGIM and SGIM Forum. They also wanted to offer SGIM members the opportunity to publish books and monographs. To stimulate such activity, Springer's book editors hosted a reception at the 2009 SGIM Annual Meeting which was well attended. One book has been published ${ }^{18}$, and several others are under development. This makes the partnership of JGIM and Springer a value-added resource for SGIM members and their drive towards scholarly productivity.

In the first two years of our editorship, Dr. Eric Bass, our immediate predecessor as editor, agreed to chair JGIM's Editorial Board. With our encouragement and cooperation, he transformed it from a mainly ceremonial Board to an activist Board that directly oversees the productivity and financial stability of the Journal. Meeting quarterly (three times by conference call and once in person at the SGIM Annual Meeting), the Editorial Board has had measurable impact on Journal policy and were heavily engaged in selecting the next JGIM co-editors.

We have also worked for almost a year with the next editors to affect a smooth transition. Facilitating this transition is the fact that the editorial office will remain in the Regenstrief
Institute and maintain the same Managing Editors, with additional assistance from a part-time Associate Managing Editor in California.

\section{GOING FORWARD}

JGIM's sails are full, and it is very likely that the next five years will be as dynamic and challenging a voyage as the past five years. JGIM will be challenged by the current business model, used by Springer and most other journal publishers, which is based mainly on individual subscriptions and print advertising. This model may no longer be viable. The increasing number of consortium agreements between publishers and academic medical centers and libraries supplies a growing cadre of readers with electronic access to the content of an increasing number and diversity of journals. Hence, subscriptions to printed journals will very likely shrink substantially, and advertisers will likely be looking elsewhere for a return on investment. It is unclear whether banner ads on journal websites will offset the lost income from print advertisements. Increasing scrutiny of biased reviews in industry-funded journal supplements will likely reduce their numbers in peerreviewed journals. Shrinking budgets of academic hospital libraries has resulted in their combining into large cooperatives that negotiate for reduced charges for consortium agreements. Requirements from the National Institutes of Health that results of NIH-funded studies be published in openaccess will decrease readers' need for to pay for journal subscriptions or buy individual articles. Journal publishers must find a new business model or risk extinction, which would leave society-sponsored journals like JGIM searching for other publishing solutions (such as self-publishing by the sponsoring society).

\section{CONCLUSIONS}

In the past five years, JGIM has made significant strides. The number and quality of submissions continue to rise. JGIM has evolved from a mostly paper-based journal to an online journal, reaching millions of global readers. JGIM is efficiently run and financially sound. Yet, challenges remain. Review times for articles undergoing full peer-review are unacceptably long, and willing reviewers are increasingly difficult to find. JGIMs Impact Factor rank dropped as a result of conscious decisions to publish more articles and types of articles that were known a priori to be less often cited. The next editors will attack these challenges with innovative changes and lead JGIM to even greater impact on the professional lives of general internists and the patients, learners, and institutions we serve.

It has been a privilege and an honor to serve JGIM and its readers, and we are deeply grateful of the SGIM Council for giving us the opportunity to learn and grow from shepherding JGIM. We are particularly grateful for the dedication, effort, and care generously donated to JGIM by its Deputy Editors, Editorial Board members, and the innumerable reviewers who have so selflessly served JGIM. It's been a great voyage, and we expect the next generation of editors to sail JGIM to spectacular destinations not even imagined. We eagerly anticipate its growth and evolution as a major voice for American medicine. 
Acknowledgments: We are eternally grateful to Jenni Clarkson for five years of dedicated service as assistant managing editor; Eric Bass, MD, MPH who as immediate-past editor and chair of the JGIM Editorial Board provided continued and energetic support; Eric Larson, MD, MPH for his leadership as the current Chair of the JGIM Editorial Board; the SGIM Council for their courage in choosing us to be editors and their unflinching support and guidance; the Deputy Editors who selflessly committed their time, energy, and talent to JGIM and the world's medical literature; and most of all to the authors who submitted their work to JGIM and the reviewers who donated their time to provide thoughtful reviews. Together they all made our job easier and immensely enjoyable, and for this we are humbled and grateful.

Corresponding Author: William M. Tierney, MD; Health Information and Translational Sciences Building, 410 West Tenth Street, Suite HS2000, Indianapolis, IN 46202, USA (e-mail: wtierney@ iupui.edu).

\section{REFERENCES}

1. Dana RH Jr. Two Years Before the Mast. New York: D. Appleton and Company; 1912

2. Gerrity MS, Tierney WM. Stepping up to the plate [editorial]. J Gen Intern Med. 2004;19:805-7.

3. Kravitz R, Franks P, Gerrity M, Feldman M, Byrne C, Tierney W. Peer reviewers' recommendations at the Journal of General Internal Medicine, 2004-2008: Style or substance. Available at: http://www.ama-assn.org/ public/peer/posters-0911.pdf. Accessed October 12, 2009.

4. Journal of General Internal Medicine. Available at: http://jgim.iusm.iu. edu/. Accessed September 20, 2009.
5. Tierney WM, Gerrity MS. The best of JGIM. J Gen Intern Med. 2006:21:1344-50.

6. ISI Web of Knowledge. Available at: http://www.isiwebofknowledge.com/. Accessed September 20, 2009.

7. Abbasi K. Let's dump impact factors. BMJ 2004; 329:0-doi:10.1136/ bmj.329.7471.0-h.

8. Bollen J, Rodriguez MO, Van de Sompel H. Journal status. Available at: arXiv:cs/0601030v1. Accessed September 20, 2009

9. Auerbach AD. Long live generalism: Hospital medicine and the Journal of General Internal Medicine. J Gen Intern Med. 2005;20:208-9.

10. Flanders SA, Centor B, Weber V, McGinn T, Desalvo K, Auerbach A. Challenges and opportunities in academic hospital medicine: report from the academic hospital medicine summit. J Gen Intern Med. 2009;24:636-461.

11. Wharam JF, Paasche-Orlow MK, Farber NJ, Sinsky C, Rucker L, Rask KJ, Figaro MK, Braddock C 3rd, Barry MJ, Sulmasy DP. High quality care and ethical pay-for-performance: a Society of General Internal Medicine policy analysis. J Gen Intern Med. 2009;24:854-9.

12. Snow V, Beck D, Budnitz T, et al. Transitions of Care Consensus Policy Statement American College of Physicians-Society of General Internal Medicine-Society of Hospital Medicine-American Geriatrics SocietyAmerican College of Emergency Physicians-Society of Academic Emergency Medicine. J Gen Intern Med. 2009;24:971-6.

13. Montori VM, Saha S, Clarke M. A call for systematic reviews. J Gen Intern Med. 2004;19:1240-1.

14. Fugh-Berman A. The corporate coauthor. J Gen Intern Med. 2005;20:546-8.

15. World Association of Medical Editors. Ghost writing initiated by commercial companies. J Gen Intern Med. 2005;20:549.

16. Tierney WM, Gerrity MS. Scientific discourse, corporate ghostwriting, journal policy, and public trust. J Gen Intern Med. 2005;20:550-1.

17. Tierney WM, Gerrity MS. Distinguished reviewers. J Gen Intern Med. 2008;23:2144.

18. Stone V, Ojikutu B, Rawlings MK, Smith KY (eds.). HIV/AIDS in U.S. Communities of Color. New York: Springer, 2009 